\title{
Retinal Ganglion Cell Topography of Five Species of Ground-Foraging Birds
}

\author{
Tracy Dolan ${ }^{a} \quad$ Esteban Fernández-Juricic ${ }^{b}$ \\ Departments of Biological Sciences, a California State University Long Beach, Long Beach, Calif., and \\ bPurdue University, West Lafayette, Ind., USA
}

\section{Key Words}

Birds - Columbiformes - Ganglion cells - Passeriformes •

Retinal topography $\cdot$ Vigilance $\cdot$ Visual acuity

\begin{abstract}
Birds that forage on the ground have been studied extensively in relation to behavioral trade-offs between foraging and scanning for predators; however, we know little about the topography of their retinas, which can influence how they gather visual information. We characterized the density of retinal ganglion cells across the retina and estimated visual acuity of four Passeriformes (European starling Sturnus vulgaris, brown-headed cowbird Molothrus ater, house sparrow Passer domesticus, house finch Carpodacus mexicanus) and one Columbiforme (mourning dove Zenaida macroura) that forage on the ground. We used cresyl violet to stain retinal ganglion cells and estimated visual acuity based on cell density and eye size. All species contained a single area centralis, where cell densities were $>20,000$ cells $/ \mathrm{mm}^{2}$. The proportion of the retina that fell in each of five cell density ranges varied between species. European starlings and house finches had the largest area of high cell density, mourning doves had the smallest. The largest proportion of the retina (>35\%) of brown-headed cowbird and house sparrow was in the second-lowest cell density range. Considering the 25th percentile of highest cell densities, house finches and European starlings showed the highest cell densities and mourn-
\end{abstract}

ing doves the lowest. Estimated visual acuity increased from house finch, house sparrow, brown-headed cowbird, European starling to mourning dove, and was associated with both retinal area and cell density. Our findings suggest that these ground foragers do not have highly specialized retinas in relation to other types of foragers (e.g. tree foragers), probably because foraging on seeds and insects from the ground is not as visually demanding; however, the studied species showed variability in retinal topography that may be related to foraging techniques, eye size constraints, and size of the area centralis.

Copyright $\odot 2010$ S. Karger AG, Basel

\section{Introduction}

The distribution of photoreceptors and retinal ganglion cells (RGCs) has been found to be heterogeneous across avian retinas [Hughes, 1977; Collin, 1999; Hart, 2001], and this has the following implications. First, sectors in the retina with a high density of photoreceptors or RGCs are expected to gather more photons or transfer more information to the brain, respectively, per degree of visual field than areas with a lower density. This could lead to functional specializations in the retina [Hayes, 1982]. Second, the heterogeneous topography of the retina can affect the visual resolution across different sectors of the visual field (e.g. higher resolution in the lateral than

\section{KARGER}

() 2010 S. Karger AG, Basel

Fax +41613061234 E-Mail karger@karger.ch www.karger.com www.karger.com/bbe
Esteban Fernández-Juricic

Department of Biological Sciences, Purdue University

Lilly Hall G-302, 915 W. State Street

West Lafayette, IN 47907 (USA)

Tel. +1 765494 6044, Fax +1 7654940876 , E-Mail efernan@purdue.edu 
the binocular visual field), which is the three-dimensional area around the head from which visual information can be gathered at any given head position [Martin, 1993]. This can lead to behavioral changes in head orientation so that animals place retinal sectors with high resolution on objects of interest, e.g. food, predators, or conspecifics [Miles and Wallman, 1993; Tisdale and Fernández-Juricic, 2009], or to changes in body position to keep the head (and the eyes) stabilized while the animal is in motion [Katzir et al., 2001; Necker, 2007].

One example of retinal specialization is the fovea, which corresponds to a depression of the retina as a result of the displacement of its inner layer [Fite and RosenfieldWessels, 1975]. In birds, the number of foveae varies, with species with one, two, or no foveae [Meyer, 1977]. For instance, diurnal predatory birds have both a central and a temporal fovea [Fite and Rosenfield-Wessels, 1975; Reymond, 1985, 1987; Inzunza et al., 1991]. However, even in birds without a pitted fovea, there is generally a sector with a higher density of photoreceptors and/or RGCs called an area [Meyer, 1977]. For example, pigeons have both an area centralis and an area dorsalis that allow individuals in a head-up position to enhance local acuity and the chances of detecting predators and inspecting the ground for food simultaneously [Hodos and Erichsen, 1990].

The density of RGCs can be used to estimate the upper limits of visual acuity or spatial resolving power [Collin and Pettigrew, 1989]. Visual acuity is important from an ecological perspective because it gives a direct indication of the distance from which animals can detect objects (e.g. predators or food patches) with enough resolution to make behavioral decisions [Kiltie, 2000]. Comparatively, larger birds have higher visual acuity than smaller ones [Brooke et al, 1999] due to variations in eye size [Kiltie, 2000]: if retinal anatomy is the same, larger-eyed birds will have higher acuity [Ross, 2000]. However, little information exists about the variation in RGC density, and visual acuity, in Passeriformes [Coimbra et al., 2006; Rahman et al., 2006, 2007].

In particular, Passeriformes that forage on the ground are an interesting group to study retinal topography because they are generally used to investigate the trade-offs between foraging and visually scanning for predators from both theoretical [McNamara et al., 1994; Fernández-Juricic et al., 2004] and empirical perspectives [Lima and Bednekoff, 1999; Roth et al., 2006]. Our goal was to study the interspecific variation in retinal topography in a group of four Passeriformes [house finch (HF) Carpodacus mexicanus, house sparrow (HS) Passer domesticus, brown-headed cowbird (BHC) Molothrus ater, and Euro- pean starling (ES) Sturnus vulgaris] and one non-Passeriforme bird [mourning dove (MD) Zenaida macroura]. All of these species forage preferentially on the ground, but specialize in targeting different types of prey items with different foraging techniques. We examined the visual abilities of each species by assessing average retinal cell density, cell soma size, retina size, and gradients of variation in cell density across the retina to construct ganglion cell density maps, and by estimating visual acuity.

\section{Methods}

We briefly provide some background information on the species studied here (in parentheses we present body masses of the sampled individuals). MDs (113.34 $\pm 15.33 \mathrm{~g})$ are generalist granivores that feed by quickly filling their crops and then move to cover to digest food. They forage by moving leaf litter with their bills to uncover food [Otis et al., 2008]. ESs (76.12 $\pm 4.04 \mathrm{~g})$ feed on invertebrates by probing the soil with their beaks [Cabe, 1993]. BHCs $(38.34 \pm 5.99 \mathrm{~g})$ feed both on seeds and insects that are stirred up by cattle in short-grazed grass. They sometimes use a technique called 'hawking', by which they walk along the ground and jump up from below to capture flying insects and gleaning insects off grass swards [Lowther, 1993]. HSs $(27.69 \pm 0.93 \mathrm{~g})$ forage on the ground and mostly feed on grain and also insects during the breeding season, but also consume supplementary food provided by people [Lowther and Calvin, 2006]. HFs (21.26 $\pm 1.15 \mathrm{~g})$ feed mostly on plant matter on and off the ground [Hill, 1993]. Raptors are the natural predators of adults in all these species.

The protocol for this study was approved by the California State University Long Beach Institutional Animal Care and Use Committee (protocol No. 220). Individuals were captured live from populations in southern California. Animals were housed on campus (Animal Research Facilities) with $3-5$ birds in a cage $(0.80$ $\times 0.55 \times 0.60 \mathrm{~m})$. The birds were kept on a 12-hour light/dark cycle at approximately $25^{\circ} \mathrm{C}$. Food and water were provided ad libitum. ESs were fed cat food (30\% crude protein, Chicken Soup for the Pet Lover's Soul Brand Cat Food; Diamond Pet Food, Lathrop, Calif., USA) supplemented with mealworms (Tenebrio molitor). HSs, HFs, and BHCs were fed mixed birdseed (Royal Feeds Leech, Feed, and Milling, Downey, Calif., USA). MDs were fed dove mix (Black Smith’s Corner Feed Store, Bellflower, Calif., USA).

Tissue Processing

Animals were euthanized with $\mathrm{CO}_{2}$ after which eyes were immediately removed. Eye axial length was measured using digital calipers to an accuracy of $0.01 \mathrm{~mm}$. Eyes were hemisected and placed in $4.0 \%$ paraformaldehyde in phosphate-buffered saline (PBS) solution at $\mathrm{pH} 7.2$ for $5 \mathrm{~min}$. The eye cup was rinsed in PBS and the retina dissected using a fine paintbrush to gently remove as much of the retinal pigmented epithelium as possible. The retina was then placed back in $4 \%$ paraformaldehyde for at least $12 \mathrm{~h}$, then removed from the paraformaldehyde and rinsed in PBS.

Radial cuts were made to allow the retina to lie flat. The retina was floated in PBS onto a gelatinized slide and using a paintbrush 
the retina was gently smoothed out and excess vitreous humor removed. The pecten was carefully removed at the base of the retina and a coverslip was placed over the tissue to hold it flat. We then took a digital photograph of the retina (Cannon Power Shot A630) to assess tissue shrinkage after processing. The slide was then placed in a vessel containing a few drops of formalin on a hot plate at $60^{\circ} \mathrm{C}$ for $2 \mathrm{~h}$ to ensure the retina adhered to the slide securely. The retina was dried in the vessel for another $24 \mathrm{~h}$ [Stone, 1981; Hart, 2002].

The retina was cleared for $20 \mathrm{~min}$ in two 10-min changes of Histo-Clear (National Diagnostics), followed by two 2-min rinses in $100 \%$ ethanol. The retina was then placed in the following sequence of solutions, each for 2 min: 95\% ethanol acidified with glacial acetic acid, $80 \%$ ethanol, $70 \%$ ethanol, and distilled water acidified with glacial acetic acid. The retina was immersed in $0.25 \%$ cresyl violet for approximately 6 min depending on the quality of the staining achieved, and then quickly rinsed in acidified distilled water, and dehydrated in $70 \%$ ethanol and $80 \%$ ethanol, each for $30 \mathrm{~s}$. The retina was placed in 95\% ethanol acidified with acetic acid for $60 \mathrm{~s}$, followed by two rinses in 100\% ethanol each for $60 \mathrm{~s}$. The tissue was differentiated in 95\% ethanol acidified with acetic acid until clear (at least $1 \mathrm{~min}$ ). This was followed by two quick rinses in $100 \%$ ethanol and the tissue was then placed back in Histo-Clear for two 10-min rinses [Stone, 1981; Boire et al., 2001; Hart, 2002]. The tissue was coverslipped with Permount (Fisher Scientific) out of Histo-Clear, and allowed to dry. The excess mounting medium was cleaned off the slide using Histo-Clear on a cotton swab and a post-processing photograph was taken.

During the dehydration portions of processing, the retinal tissue could shrink. The degree of retinal tissue shrinkage may vary between species [Stone, 1981], potentially influencing the estimates of RGC density. The adherence of the retina onto the gelatinized slide was meant to minimize shrinkage. Nevertheless, we measured the area of the retina with ImageJ (http://rsb.info.nih. gov/ij/) before and after processing to determine if a correction factor was necessary. When tissue shrinkage occurred, we estimated a percentage change in tissue size. The area captured in the photographs was $0.022 \mathrm{~mm}^{2}$, so the correction was $0.022+(0.022$ $x$ percentage of shrinkage). Cell density was then calculated by dividing the number of cells in each photograph by the corrected tissue area in each photograph.

Stained ganglion cells were then examined under the microscope at $\times 40$ power. A $1 \times 2 \mathrm{~mm}$ grid was drawn by hand onto the coverslip to divide the retina into quadrats. We also produced a hand-drawn map of the retina with the grid on it to track the location of the photographs within each quadrat. We photographed the ganglion cell layer with a Moticam 2000 microscope camera using Motic Image Plus 2.0. Each quadrat was approximately 7 photographs wide and 3 photographs high, with each photograph capturing $0.022 \mathrm{~mm}^{2}$. We photographed the cell layer in a predetermined spatial order to avoid overlap among photographs by moving the microscope stage a constant distance between photographs and tracking visually the location of groups of cells along the edges of consecutive photographs to avoid double counting. The spatial order consisted of three rows of photographs in each quadrat, with photographs 1-7 taken on the bottom row (from left to right), photographs 8-14 taken on the middle row (from right to left), and photographs 15-21 taken on the upper row (from left to right). We then counted the number of
RGCs per photograph with ImageJ to estimate density. We report density values as the number of RGCs per square millimeter. The RGC layer also includes other cell types, such as amacrine and glial cells. We established standard criteria for identifying ganglion cells based on their relatively large soma size, Nissl accumulation in the cytoplasm, and staining of the nucleus [Hughes, 1977; Freeman and Tancred, 1978; Stone, 1981; Rahman et al., 2006; Rahman et al., 2007].

\section{Ganglion Cell Density Distribution}

To visualize the ganglion cell density distribution across the retina, we constructed topographic density maps. We used a coordinate system on a Cartesian plane to plot cell density based on the $1 \times 2 \mathrm{~mm}$ grid system and the order in which photographs were taken. X and Y represented the horizontal and vertical, respectively, placement of each sampled photograph, which had a single cell density (cells $/ \mathrm{mm}^{2}$ ) value. Cell density values of a whole retina were imported into ESRI ArcMap 9.2 as X-Y coordinate data.

A cell density layer was then plotted using the Quantities Graduated Colors Symbology option in ArcMap 9.2. Each data point was visualized as a color that corresponded to cell density ranges. Linear interpolation between points created isodensity boundary lines around each cell density range area. These lines were then smoothed by hand [Stone, 1981; Moroney and Pettigrew, 1987; Wathey and Pettigrew, 1989]. We constructed two versions of the topographic maps for each species. In the first version, we used different density ranges for each species to better visualize areas with high cell density (e.g. area centralis). In the second version, we standardized cell density ranges across species (0$4,999,5,000-9,999,10,000-14,999,15,000-19,999$, and $>20,000$ cells $/ \mathrm{mm}^{2}$ ). We then measured the retinal area of each standardized cell density range with ImageJ to establish changes in the proportional retinal area occupied by each range between species.

\section{Ganglion Cell Soma Area}

We examined visually RGC soma area for all the species in the central and peripheral areas of the retina. Only in the HS and ES did we measure RGC soma area (one retina per species) at the center and periphery of the retina. In each retina, we selected randomly 4-5 photographs from each quadrat (see above), and measured 10 cells per photograph, totaling 1,236 and 1,910 RGCs in the HS and ES retinas, respectively. Using ImageJ, we measured cell soma area $\left(\mathrm{mm}^{2}\right)$ by tracing the outline of the cell.

\section{Visual Acuity}

Visual acuity depends on various factors: (a) eye size and shape; (b) photoreceptor density; (c) RGC density, and (d) different optical properties of the eyes [Kirk and Kay, 2004]. Our model species have approximately similar eye shapes and optics because they are diurnal [Martin, 1985; Hall and Ross, 2007]. In the areas of high concentration of photoreceptors (e.g. fovea or area centralis depending on the species), the density of RGCs is considered to give a better indicator of visual resolution than the density of photoreceptors [e.g. Boire et al., 2001], partially due to visual summation. One of the advantages of estimating visual acuity based on the fovea or area centralis is that the number of amacrine cells is proportionally lower (and RGCs higher), which minimizes the bias of cresyl violet staining [Hayes and Holden, 1983]. Other studies have shown that the distribution of RGC den- 
sity classes across the retina is not substantially influenced by the inclusion of displaced amacrine cells [Collin and Pettigrew, 1988; Inzunza et al., 1991; Collin, 1999; Hart, 2002]. Therefore, we based our estimates of visual acuity on RGCs from areas in the retina with high cell density, following Collin and Pettigrew [1989].

Previous studies have estimated the fovea as having the highest 50th percentile of cell density [Franco et al, 2000]. We were not able to definitively establish the presence of a foveal pit in the retina of our model species because we did not perform crosssections of the retinas. However, we calculated two estimates of areas of high concentration of RGC. We estimated cell density from areas in the retina with the highest 50 th percentile $\left(\mathrm{RGC}_{50}\right)$ and 25 th percentile $\left(\mathrm{RGC}_{25}\right)$ cell densities.

To estimate visual acuity, we used the sampling theorem [Hughes, 1977] by considering both cell density and eye size. We first calculated the average posterior nodal distance (PND) for each species, which is defined as 'the distance between the posterior nodal point of the eye and the anterior reflective surface of the retina' [Reymond, 1985]. This was estimated by measuring the axial length of the eye and multiplying it by 0.60 , which is the axial length/PND ratio [Hughes, 1977; Martin, 1993; Boire et al., 2001 in most diurnal avian species. PND is an important parameter because it determines the area of the retina that an image is projected onto. Increasing PND can allow an image to be spread over more photoreceptors and thus increase the amount of detail that can be resolved. To estimate visual acuity from ganglion cell density, we first calculated the retinal magnification factor (RMF), which is the linear distance on the retina that subtends $1^{\circ}$ [Pettigrew et al., 1988], as:

$$
R M F=\frac{2 \pi P N D}{360}
$$

Our estimate of visual acuity was $\mathrm{F}_{\mathrm{n}}$, the highest spatial frequency that can be detected, which was calculated in cycles per degree as:

$$
F_{n}=\frac{R M F}{2} \sqrt{\frac{2 D}{\sqrt{3}}}
$$

where D represents RGC density (cells $/ \mathrm{mm}^{2}$ ) [Williams and Coletta, 1987].

This study presents for the first time estimates of $\mathrm{RGC}_{50}$ and $\mathrm{RGC}_{25}$ density and visual acuity of ESs, HSs, and HFs; however, the $\mathrm{RGC}_{50}$ and $\mathrm{RGC}_{25}$ density values from MDs and BHCs were taken from Blackwell et al. [2009], but were estimated in the same way as in the present study.

\section{Statistical Analysis}

We did not record major deviations from normality in the dependent variables, so we used general linear models to establish between-species differences in visual acuity, maximum and mean density of RGCs, total area of the retina, area of the different cell density ranges, and eye size. We examined pair-wise differences between species with planned comparisons, which are post hoc tests between levels of categorical factors (e.g. species) that are conducted after finding significant differences in an overall model. We also assessed the contribution of eye size and cell density in the variation in visual acuity with a general linear model and calculated the partial eta squared, which provides an estimate of the variance accounted for in a sample. Partial eta-squared values are not additive.

\section{Results}

We extracted retinas from 7 mourning doves, 7 European starlings, 7 brown-headed cowbirds, 6 house sparrows, and 5 house finches. Of these retinas, 5 per species were in good condition for most of the analyses; however, representative topographic maps could be made out of fewer retinas (MD, 2 retinas; ESs, 4 retinas; BHCs, 3 retinas; HSs, 3 retinas, and HFs, 3 retinas). We chose one representative retina per species to draw the topographic maps.

\section{Eye Size}

Axial length varied among species, with the largest being the MD $(9.28 \pm 0.06 \mathrm{~mm})$, followed by the ES $(7.74$ $\pm 0.03 \mathrm{~mm})$, BHC $(6.71 \pm 0.05 \mathrm{~mm})$, HS $(6.07 \pm 0.06$ $\mathrm{mm})$, and $\mathrm{HF}\left(5.67 \pm 0.02 \mathrm{~mm} ; \mathrm{F}_{4,20}=1,373.1, \mathrm{p}<0.001\right)$. All planned comparisons between pairs of species were significant $(\mathrm{p}<0.05)$.

\section{RGC Soma Size}

In all the model species, the soma size of the RGCs was visually larger in the peripheral areas in relation to the central areas of the retina (fig. 1). To corroborate this pattern, we measured cell soma size in two of our model species. RGC soma size was larger in the peripheral than in the central areas of the retinas of HSs (central, 0.000029 $\pm 0.000001 \mathrm{~mm}^{2}$; peripheral, $0.000042 \pm 0.000001$ $\mathrm{mm}^{2} ; \mathrm{F}_{1,1234}=48.17, \mathrm{p}<0.001$ ), and ESs (central, 0.000019 $\pm 0.000001 \mathrm{~mm}^{2}$; peripheral, $0.000026 \pm 0.000001$ $\left.\mathrm{mm}^{2} ; \mathrm{F}_{1,1908}=129.68, \mathrm{p}<0.001\right)$.

\section{RGC Density and Retinal Area}

The maximum RGC density did not vary significantly among species $\left(\mathrm{MD}, 21,026.93 \pm 513.40 \mathrm{cells} / \mathrm{mm}^{2}\right.$; ES, $25,316.81 \pm 1,097.73$ cells $/ \mathrm{mm}^{2}$; BHC, $21,665.26 \pm$ $1,882.95$ cells $/ \mathrm{mm}^{2} ; \mathrm{HS}, 23,920.36 \pm 1,349.59$ cells $/ \mathrm{mm}^{2}$, and HF, 25,256.24 \pm 842.18 cells $/ \mathrm{mm}^{2}$ ), although there was a nonsignificant trend by which HFs and ESs showed the highest density values $\left(\mathrm{F}_{4,20}=2.66, \mathrm{p}=0.063\right)$.

$\mathrm{RGC}_{25}$ density varied significantly among species $\left(\mathrm{MD}, 17,295.84 \pm 539.81 \mathrm{cells} / \mathrm{mm}^{2}\right.$; ES, 20,391.61 \pm 956.11 cells $/ \mathrm{mm}^{2}$; BHC, 18,100.64 $\pm 1,579.39$ cells $/ \mathrm{mm}^{2}$; HS, $19,828.53 \pm 980.85$ cells $/ \mathrm{mm}^{2}$, and HF, 21,527.42 \pm 645.94 cells $\left./ \mathrm{mm}^{2} ; \mathrm{F}_{4,20}=2.91, \mathrm{p}=0.048\right)$. However, the only significant difference was a higher $\mathrm{RGC}_{25}$ density in HFs in relation to MDs $\left(\mathrm{F}_{4,20}=8.81, \mathrm{p}=0.007\right)$; all other between-species differences were not significant $(\mathrm{p}>$ 0.05). RGC $_{50}$ density did not vary significantly among species $\left(\mathrm{F}_{4,20}=2.23, \mathrm{p}=0.103\right): \mathrm{MD}, 15,783.93 \pm 352.17$ cells $/ \mathrm{mm}^{2}$; ES, $18,666.78 \pm 938.78$ cells $/ \mathrm{mm}^{2}$; BHC, 
$16,359.59 \pm 1,450.29$ cells $/ \mathrm{mm}^{2} ;$ HS, $17,461.84 \pm 1,081.04$ cells $/ \mathrm{mm}^{2}$, and HF, 19,209.19 \pm 715.69 cells $/ \mathrm{mm}^{2}$.

The area of the retina prior to staining varied significantly among species (MD, $135.35 \pm 7.92 \mathrm{~mm}^{2}$; ES, $109.59 \pm 7.00 \mathrm{~mm}^{2}$; BHC, $96.70 \pm 3.00 \mathrm{~mm}^{2}$; HS, 74.00 $\pm 4.02 \mathrm{~mm}^{2}$, and HF, $54.55 \pm 2.97 \mathrm{~mm}^{2} ; \mathrm{F}_{4,20}=35.06$; $\mathrm{p}<0.001)$. The MD retinal area was significantly larger than those of the other four species $\left(\mathrm{F}_{1,20}=79.01 ; \mathrm{p}<\right.$ 0.001). The ES retinal area was smaller than that of the $\mathrm{MD}\left(\mathrm{F}_{1,20}=13.22, \mathrm{p}=0.002\right)$, not significantly different from that of the BHC $\left(\mathrm{F}_{1,20}=2.85, \mathrm{p}=0.107\right)$, but larger than those of the HS and $\operatorname{HF}\left(\mathrm{F}_{1,20}=47.01, \mathrm{p}<0.001\right)$. The $\mathrm{BHC}$ retinal area was larger than those of the HS and HF $\left(\mathrm{F}_{1,20}=24.06, \mathrm{p}<0.001\right)$. Finally, the HS retina was larger than that of the $\operatorname{HF}\left(\mathrm{F}_{1,20}=6.49, \mathrm{p}=0.019\right)$.

Given the between-species differences in retinal area, we pooled information from all species to analyze the association between retinal area and cell density. We found that larger retinas tended to have lower $\mathrm{RGC}_{25}$ density $\left(\mathrm{r}=-0.41, \mathrm{p}=0.039, \mathrm{RGC}_{25}\right.$ density $=22,897.63-34.48 \times$ area of the retina). However this relationship was not significant when considering $\mathrm{RGC}_{50}$ density $(\mathrm{r}=-0.33$, $\mathrm{p}=0.107)$ or maximum RGC density $(\mathrm{r}=-0.33, \mathrm{p}=0.110)$. Our results suggest that $\mathrm{RGC}_{25}$ density is negatively associated with retinal area across species.

\section{Distribution of RGC Density}

Topographic plots show the distribution of RGC density across the retina of the five species (fig. 2). Overall, all species showed one area with a high concentration of RGCs in the central part of the retina, which can be considered to be the area centralis.

We also constructed topographic maps with standardized cell density ranges to compare across species the proportional area of the retina occupied by each cell density range (fig. 3). Taking into account all individuals from which topographic maps could be obtained, we measured the proportional retinal area in each cell density range. We found a significant interaction effect between species and cell density range $\left(\mathrm{F}_{16,50}=3.19, \mathrm{p}<0.001\right)$, by which the proportional area per density range varied among species (fig. 4).

The MD had all five cell density ranges, with the majority of the retina (67.5\%) falling in the two ranges that covered 5,000-14,999 cells $/ \mathrm{mm}^{2}$ (fig. 3, 4). The ES also had five cell density ranges, each of them covering less than $26 \%$ of the retinal area, with the higher densities in the $10,000-14,999$ and $>20,000$ cells $/ \mathrm{mm}^{2}$ ranges (fig. 3 , 4). The BHC had five cell density ranges (although the individual shown in the topographic map in figure 3 did
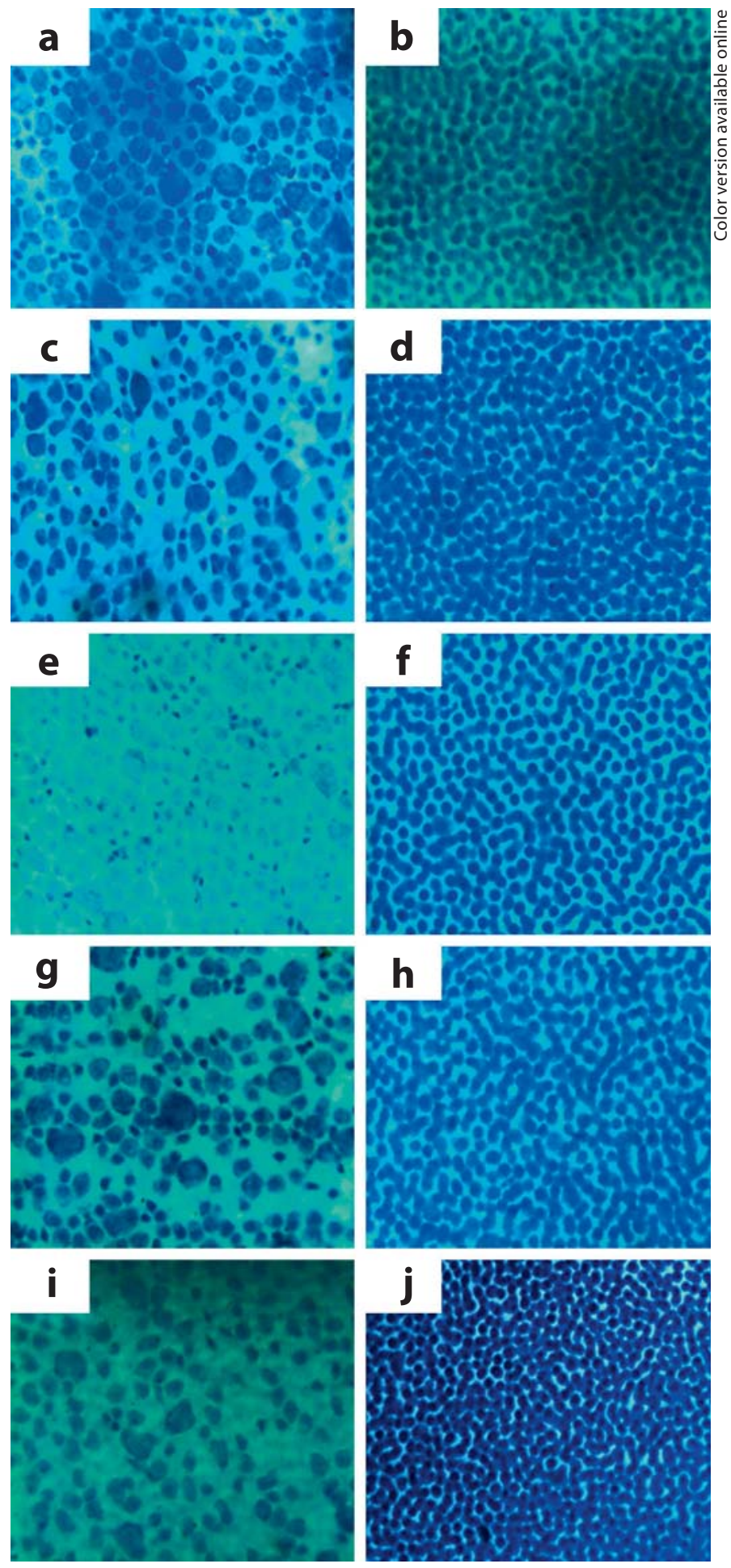

Fig. 1. Light photograph of Nissl-stained neurons in the peripheral (left) and central (right) areas in the ganglion cell layer of the $\operatorname{MD}(\mathbf{a}, \mathbf{b})$, ES (c, d), BHC (e, f), HS ( $(\mathbf{g}, \mathbf{h})$, and HF (i, j). Each photograph covers an area of $0.022 \mathrm{~mm}^{2}$. 
Fig. 2. Examples of retinal topographic maps in the five studied species: MD (a; right eye), ES (b; left eye), BHC (c; left eye), HS (d; left eye), and HF (e; left eye). Numbers represent the upper cell density (cells/ $\mathrm{mm}^{2} \times 10^{3}$ ) of the density range. The pecten is indicated by the black shape in the lower half of each diagram.

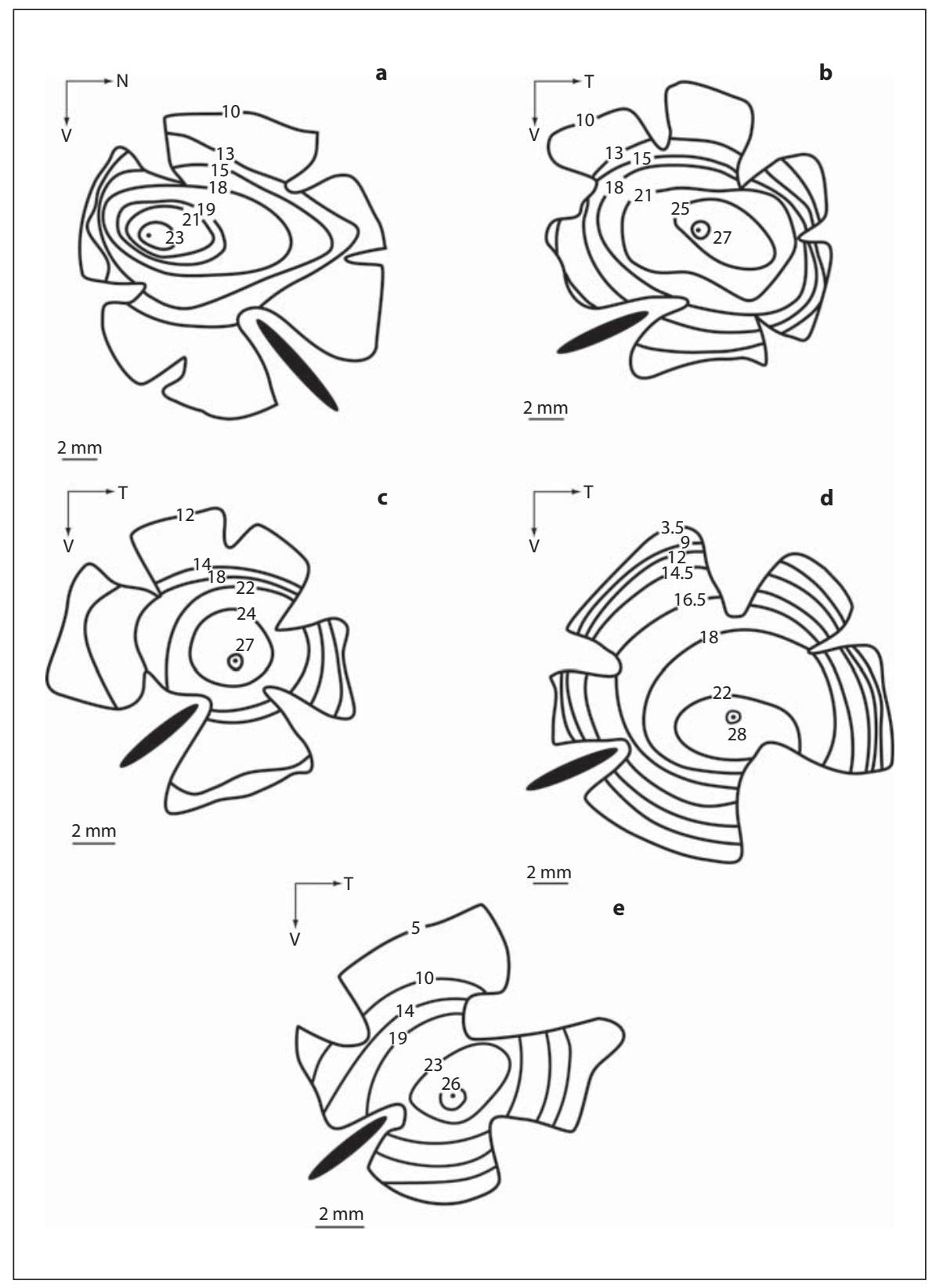

not have the $<4,999$ cells $/ \mathrm{mm}^{2}$ range). A large proportion $(41.3 \%)$ of the BHC retina had $5,000-9,999$ cells $/ \mathrm{mm}^{2}$ (fig. 3, 4). None of the HSs sampled had any portions of the retina with $<4,999$ cells $/ \mathrm{mm}^{2}$, with the largest area of the retina falling in the same 5,000-9,999 cells $/ \mathrm{mm}^{2}$ range as the BHC (fig. 3, 4). The HF had the five cell density ranges, each of them covering less than $31 \%$ of the retina (fig. 3,4 ). The largest area in the HF retina fell in the $15,000-19,999$ cells $/ \mathrm{mm}^{2}$ range.
Visual Acuity

Visual acuity based on the $\mathrm{RGC}_{25}$ density (visual acuit $_{25}$ ) differed significantly among species (MD, $6.89 \pm$ 0.09 cycles/degree; ES, $6.29 \pm 0.11$ cycles/degree; BHC, $5.10 \pm 0.25$ cycles/degree; HS, $4.88 \pm 0.09$ cycles/degree; $\mathrm{HF}, 4.69 \pm 0.06$ cycles/degree; $\mathrm{F}_{4,20}=49.08, \mathrm{p}<0.001$ ). $\mathrm{MD}$ visual acuity ${ }_{25}$ was significantly higher than those of the other four species $\left(\mathrm{F}_{1,20}=116.11, \mathrm{p}<0.001\right)$. ES visual acuity ${ }_{25}$ was significantly higher than those of BHCs, 
Fig. 3. Retinal topographic maps with standardized range boundaries of five species of ground foragers: MD (a; right eye), ES (b; left eye), BHC (c; left eye), HS (d; left eye), and HF (e; left eye). The pecten is indicated by the black shape in the lower half of each diagram. Standardized range boundaries: 5 (0-4,999 cells $\left./ \mathrm{mm}^{2}\right), 10$ (5,000-9,999 cells $\left./ \mathrm{mm}^{2}\right), \quad 15 \quad(10,000-$ 14,999 cells $\left./ \mathrm{mm}^{2}\right), 20(15,000-19,999$ cells/ $\left.\mathrm{mm}^{2}\right)$, and $>20 \quad\left(>20,000\right.$ cells $\left./ \mathrm{mm}^{2}\right)$. Numbers represent the upper cell density (cells $/ \mathrm{mm}^{2} \times 10^{3}$ ) of the density range.

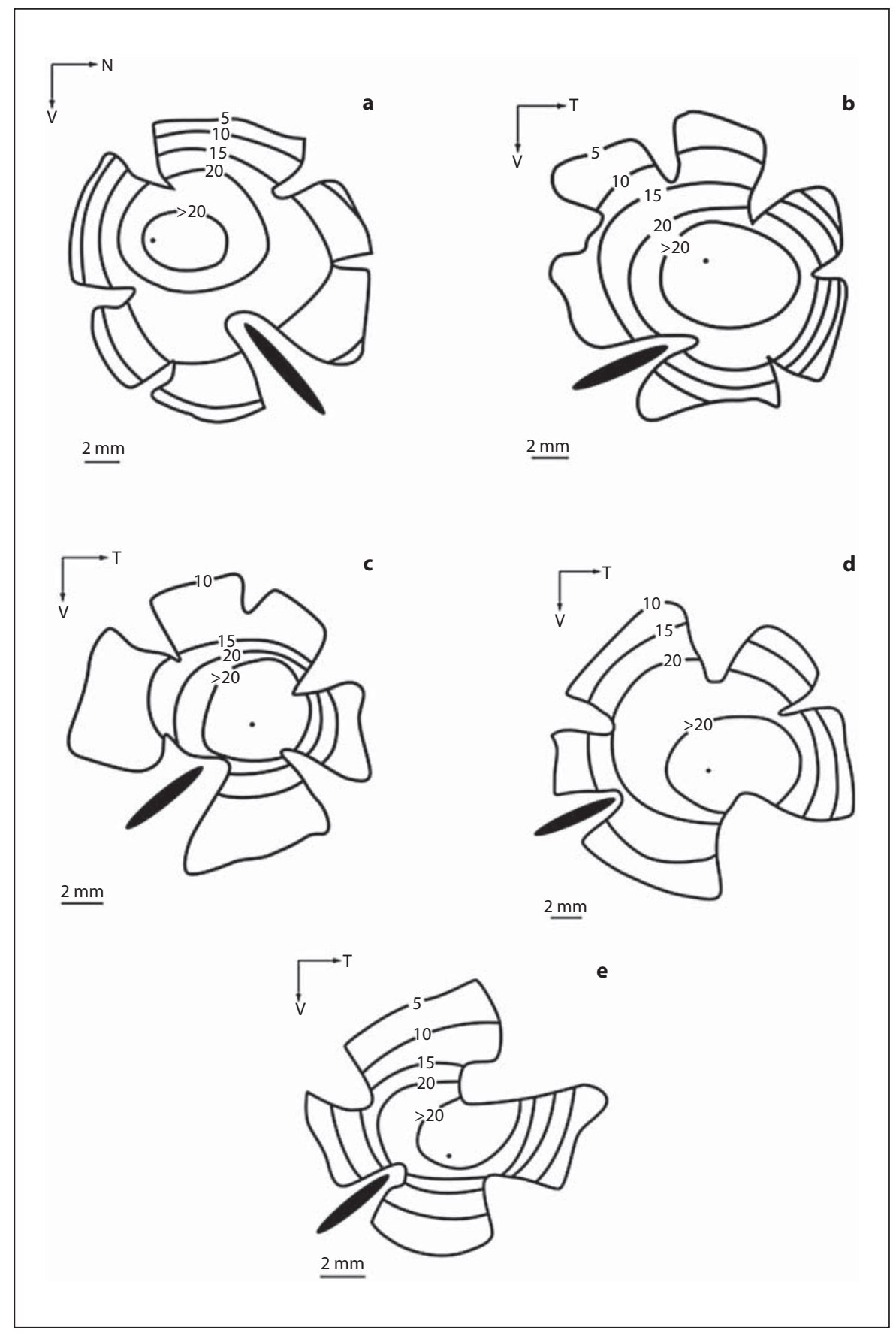

HSs, and HFs $\left(\mathrm{F}_{1,20}=75.60, \mathrm{p}<0.001\right)$. BHCs had higher visual acuity ${ }_{25}$ than HSs and HFs $\left(\mathrm{F}_{1,20}=3,450.34, \mathrm{p}<\right.$ $0.001)$, whereas the latter two species did not differ significantly in visual acuity $y_{25}\left(\mathrm{~F}_{1,20}=0.97, \mathrm{p}=0.336\right)$.

Visual acuity based on $\mathrm{RGC}_{50}$ density (visual acuity ${ }_{50}$ ) also differed significantly among species (MD, $6.53 \pm$ 0.06 cycles/degree; ES, $5.93 \pm 0.14$ cycles/degree; BHC,
$4.82 \pm 0.24$ cycles/degree; HS, $4.54 \pm 0.13$ cycles/degree; $\mathrm{HF}, 4.40 \pm 0.06$ cycles/degree; $\mathrm{F}_{4,20}=44.45, \mathrm{p}<0.001$ ). MD visual acuity 50 was higher than those of the other four species $\left(\mathrm{F}_{1,20}=104.68, \mathrm{p}<0.001\right)$. ES visual acuity $y_{50}$ was significantly higher than those of BHCs, HSs, and HFs $\left(F_{1,20}=68.68, p<0.001\right)$. BHC visual acuity $y_{50}$ was not significantly different from that of HSs and HFs 
Fig. 4. Proportion of total retinal area per RGC density range in five bird species.

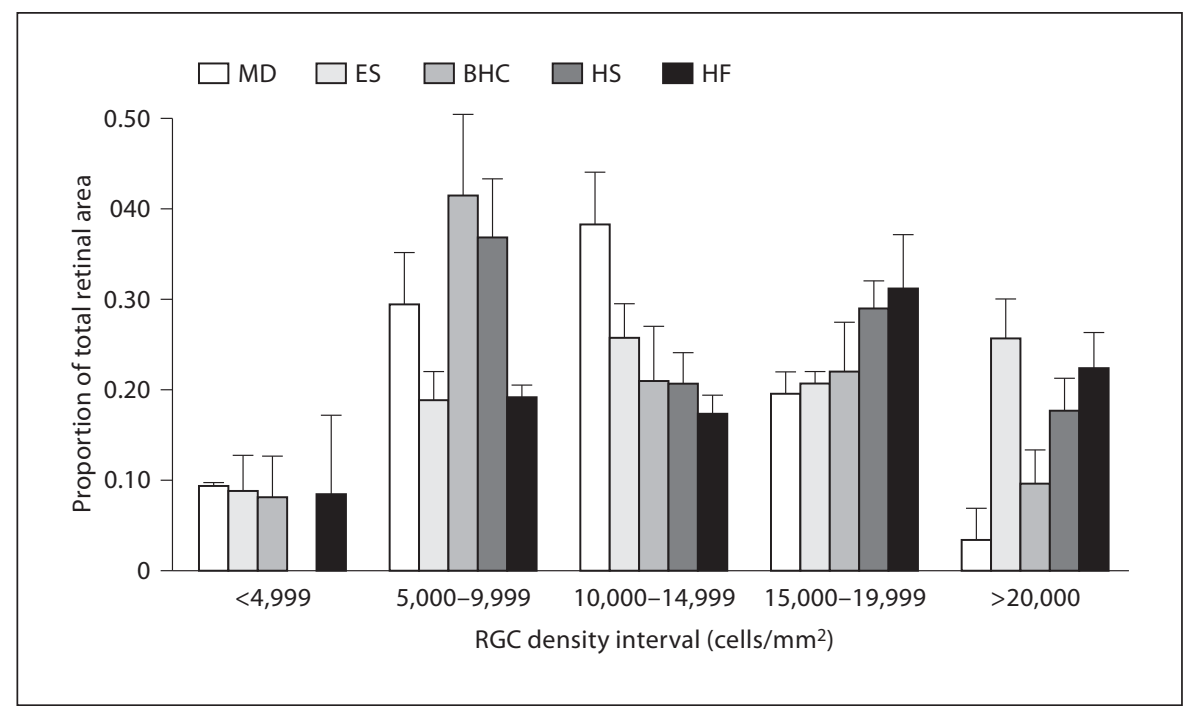

$\left(F_{1,20}=3.97, p=0.060\right)$. Finally, there was no significant difference in visual acuity $y_{50}$ between HSs and HFs $\left(\mathrm{F}_{1,20}=0.48, \mathrm{p}=0.493\right)$.

Pooling retinas from all species, we found that retinal area $\left(\mathrm{F}_{1,22}=84.36, \mathrm{p}<0.001\right.$, partial eta squared $\left.=0.79\right)$ explained a greater proportion of the variability in visual acuity $_{25}$ than $\mathrm{RGC}_{25}$ density $\left(\mathrm{F}_{1,22}=9.96, \mathrm{p}=0.004\right.$, partial eta squared $=0.31)$. Similarly, retinal area $\left(\mathrm{F}_{1,22}=\right.$ 94.48, $\mathrm{p}<0.001$, partial eta squared $=0.81)$ explained a greater proportion of the variability in visual acuity $y_{50}$ than $\mathrm{RGC}_{50}$ density $\left(\mathrm{F}_{1,22}=12.28, \mathrm{p}=0.002\right.$, partial eta squared $=0.36$ ). However, in both analyses RGC density significantly accounted for the variability in visual acuity.

\section{Discussion}

This study assessed variations in the density and distribution of RGCs across the retinas of four passerine and one non-passerine species that forage on the ground. Despite some similarities among them (single area centralis, decrease in cell soma size towards the center of the retina, and similar peak RGC density), we found some differences in retinal topography, RGC density, and visual acuity.

The topographic maps revealed variations in the proportion of the retina that fell in each ganglion cell density range. HFs and ESs had the proportionally largest area of highest cell density, whereas MDs had the smallest, according to the cell density ranges we used. Interest- ingly, HFs showed the highest RGC density, and MDs the lowest. One hypothesis that may deserve attention is that to compensate for the reduction in spatial resolving power in smaller eyes, retinas could have a relatively larger area centralis with relatively higher RGC density (see Results: association between retinal area and cell density when pooling species). In a comparative analysis controlling for phylogenetic effects, a negative relationship between eye size and cell density in the area centralis would be predicted. More comparative information on the degree of variability in the size of the area centralis and RGC density is necessary.

The highest density area in the MD was slightly displaced towards the temporal sector of the retina that projects into the front of the beak, likely to increase resolution when foraging. A large proportion of the MD retina (67.5\%) had relatively lower values of RGC density (5,00014,999 cells $/ \mathrm{mm}^{2}$ ). Low RGC density has also been reported in other large non-passerine species [e.g. ostrich Struthio camelus, Boire et al., 2001]. The evolutionary pressure for high-density retinal areas may not be that strong in the MD given that higher visual resolution can be achieved through its larger eye.

HSs did not have regions in the retina that were below the lower range of cell density $\left(5,000\right.$ cells $\left./ \mathrm{mm}^{2}\right)$, which was located at the periphery of the retina. Compared to the other studied species, lacking the lowest cell density range may confer HSs enhanced peripheral spatial resolution that may aid in searching for food items (e.g. mostly grains, insects, and arthropods) or detecting predators while individuals are head down [Fernández-Juricic et al., 2008]. 
The topography of the HS retina was very similar to that of a sister species, the tree sparrow Passer montanus, which also has a single area centralis at the center of the retina with a similar peak at around 27,000 cells $/ \mathrm{mm}^{2}$ [Rahman et al., 2007]. This degree of anatomical similarity may be related to their common phylogeny and ecology.

A large proportion of the retina of BHCs fell into the second-lowest cell density range $\left(5,000-9,999\right.$ cells $\left./ \mathrm{mm}^{2}\right)$, which may lead to low spatial resolving power in the peripheral areas of the retina. This pattern is similar to that of the Indian blue-shouldered peafowl Pavo cristatus, which also has a large proportion of its retina under 10,000 cells $/ \mathrm{mm}^{2}$ [Hart, 2002]. However, the quail, another ground forager, has a comparatively greater proportion of the retina over the 10,000 cells $/ \mathrm{mm}^{2}$ range [Budnik et al., 1984]. Future research should address whether variations in cell density at the periphery of the retina are related to phylogeny, diet, or patterns of vigilance behavior.

ESs have interesting visual properties, e.g. large degree of eye movement [Martin, 1986], eye asymmetry leading to a ramp retina that works as an accomodatory mechanism to focus on near and distant objects simultaneously [Martin, 1986], higher abundance of long-wave-sensitive cones in the ventronasal retina and of ultraviolet-sensitive cones in the dorsotemporal retina [Hart et al., 1998]. We found that the area with the highest cell density range had the largest proportion of retinal area of the five studied species. This area could be beneficial in the visual location and manipulation of food items, particularly when starlings inspect visually their bill tips [Martin, 1986]. Starlings seek invertebrates by inserting their closed bills into the ground, opening their mandibles wide, and then moving their eyes forward to determine the presence of food items (e.g. probing) [Feare, 1984]. Having a large and high-density retinal area may enhance spatial resolving power around the bill when the eyes are converged and more closely aligned with the bill tip.

We established that all studied species contained a single area with high RGC density $>20,000$ cells $/ \mathrm{mm}^{2}$. A single area is characteristic of other ground-foraging birds (topographic maps available at: http://www.retinalmaps.com.au/), such as Japanese quail Coturnix coturnix japonica [Ikushima et al., 1986], domestic chicken Gallus gallus domesticus [Ehrlich, 1981], and tree sparrows [Rahmen et al., 2007]. However, the jungle crow Corvus macrorhynchos, a generalist that forages on the ground, has both an area centralis and another area of high cell density in the dorsal-temporal region [Rahman et al., 2006]. Furthermore, peak RGC densities of our model species were within or in the lower range of other ground foragers, e.g. 25,600 cells $/ \mathrm{mm}^{2}$ (jungle crow C. macrorhynchos [Rahman et al., 2006]), 35,000 cells $/ \mathrm{mm}^{2}$ (Japanese quail [Ikushima et al., 1986]), or 35,609 cells $/ \mathrm{mm}^{2}$ (Indian blue-shouldered peafowl [Hart, 2002]), but considerably lower than in tree foragers, e.g. $>48,000$ cells $/ \mathrm{mm}^{2}(P i-$ tangus sulphuratus and Myiozetetes cayanensis [Coimbra et al., 2006]). Ground foraging may not be as visually demanding as aerial hunting, as aerial hunters need to track and capture fast moving insects, which may require higher visual resolution.

There is empirical evidence showing that histological estimates of acuity, particularly with RGCs in the fovea or area centralis, give a reasonable approximation to the upper levels of behavioral visual acuity [Tiao and Blakemore, 1976; Emerson, 1980; Vaney, 1980; Harman et al., 1986; Pettigrew et al., 1988; Wathey and Pettigrew, 1989]. Our histological estimates of visual acuity (in cycles/degree: MD, 6.89; ES, 6.29; BHC, 5.10; HS, 4.88, and HF, 4.69) were lower than in other species previously studied also using similar techniques (in cycles/degree: barn owl Tyto alba, 8; ostrich S. camelus, 19; sacred kingfisher Halcyon sancta, 26, and laughing kookaburra Dalceo gigas, 41) [Moroney and Pettigrew, 1987; Wathey and Pettigrew, 1989; Boire et al., 2001]. This difference is expected given the comparatively smaller body and eye size of our studied species as well as a less specialized foraging ecology than that of kingfishers and owls.

Previous studies that explored the selective factors shaping the evolution of visual systems with high visual resolution in birds have used eye size as a proxy of visual acuity [Garamszegi et al., 2002; Thomas et al., 2004, 2006; Hall and Ross, 2007]. Our findings support the use of eye size due to its larger contribution to the variation in visual acuity compared with RGC density, mostly because how visual acuity is calculated. However, the effects of RGC density were significant, which suggests that future comparative studies ought to take cell density into consideration, too. An important consideration is that not all RGC types that cresyl violet stains may be involved in visual spatial resolution, which could generate a bias particularly if the proportion of these cells varies interspecifically. Nonetheless, our study provides new comparative data on retinal topography that in combination with previous information [Collin, 2008] can be used to address important questions in avian visual ecology, such as the relationship among visual acuity, eye size, and RGC density, and the potential association between retinal topography and vigilance behavior in birds. 


\section{Acknowledgments}

We thank Ron Treminio, Melanie Llaben, Nellie Hayin, Christina Thabit, Mihn Nguyen, Robyn Bolwby, Greg Marony, Mark Malit, Kristen Malabanan, Marc Cepeda, Flavio Sanchez, Shanika Lewis, Mary Fanous, Alexandra St. Mark, Maureen Angela
Bermudez, Gisela Pimentel, and Susanne Whitcomb for their help during this study; Tim Morgan, Karin De Collibus, and Todd Pitlik for their help in capturing birds; Rodney McPhail for his help with the topographic maps, and Vanessa Tisdale for her feedback. This study was funded by National Science Foundation DBI0641550 and Sigma Xi.

\section{References}

Blackwell BF, Fernández-Juricic E, Seamans TW, Dolan T (2009): Avian visual system configuration and behavioural response to object approach. Anim Behav, in press.

Boire D, Dufour JS, Théoret H, Ptitio M (2001): Quantitative analysis of the retinal ganglion cell layer in the ostrich, Struthio camelus. Brain Behav Evol 58:343-355.

Brooke ML, Hanley S, Laughlin SB (1999): The scaling of eye size with body mass in birds. Proc R Soc London B 266:405-412.

- Budnik V, Mpodozis J, Varela FJ, Maturana HR (1984): Regional specialization of the quail retina: ganglion cell density and oil droplet distribution. Neurosci Lett 51:145-150.

Cabe PR (1993): European starling (Sturnus vulgaris); in Poole A (ed): The Birds of North America Online. Ithaca, Cornell Lab of Ornithology. http://bna.birds.cornell.edu/bna/ species/048.

-Coimbra JP, Marceliano MLV, Andrade-da-Costa BLS, Yamada ES (2006): The retina of tyrant flycatchers: topographic organization of neuronal density and size in the ganglion cell layer of the great kiskadee Pitangus sulphuratus and the rusty margined flycatcher Myiozetetes cayanensis (Aves: Tyrannidae). Brain Behav Evol 68:15-25.

Collin SP (1999): Behavioural ecology and retinal cell topography; in Archer SN, Djamgoz MBS, Loew ER, Partridge JC, Bellarga S (eds): Adaptive Mechanisms in the Ecology of Vision. Dordrecht, Kluwer, pp 509-535.

Collin SP (2008): A database of retinal topography maps. Clin Exp Optom 91:85-95.

Collin SP, Pettigrew JD (1988): Retinal ganglion cell topography in teleosts: a comparison between Nissl-stained material and retrograde labeling from the optic nerve. J Comp Neurol 276:412-422.

Collin SP, Pettigrew J (1989): Quantitative comparisons of the limits on visual spatial resolution set by the ganglion cell layer in twelve species of reef teleosts. Behav Evol 34:184192.

Ehrlich D (1981): Regional specialization of the chick retina as revealed by the size and density of neurons in the ganglion cell layer. J Comp Neurol 195:643-657.

Emerson VF (1980): Grating acuity of the golden hamster. Exp Brain Res 38:43-52.
Feare CJ (1984): The Starling. Oxford, Oxford University Press.

-Fernández-Juricic E, Kerr B, Bednekoff PA, Stephens DW (2004a): When are two heads better than one? Visual perception and information transfer affect vigilance coordination in foraging groups. Behav Ecol 15:898-906.

Fernández-Juricic E, Erichsen JT, Kacelnik A (2004b): Visual perception and social foraging in birds. Trends Ecol Evol 19:25-31.

Fernández-Juricic E, Gall MD, Dolan T, Tisdale V, Martin GR (2008): The visual fields of two ground foraging birds, house finches and house sparrows, allow for simultaneous foraging and anti-predator vigilance. Ibis 150: 779-787.

Fite KV, Rosenfield-Wessels S (1975): A comparative study of deep avian foveas. Brain Behav Evol 12:97-115.

-Franco ECS, Finlay BL, Silviera LCL, Yamada ES, Crowley JC (2000): Conservation of absolute foveal area in New World monkeys: a constraint on eye size and conformation. Brain Behav Ecol 56:276-286.

Freeman B, Tancred E (1978): The number and distribution of ganglion cells in the retina of the brush-tailed possum, Trichosurus vulpecula. J Comp Neurol 177:557-567.

-Garamszegi LZ, Moller AP, Erritzoe J (2002): Coevolving avian eye size and brain size in relation to prey capture and nocturnality. Proc Biol Sci 269:961-967.

Hall MI, Ross CF (2007): Eye shape and activity pattern in birds. J Zool 271:437-444.

Harman AM, Nelson JE, Crewther SG, Crewther DP (1986): Visual acuity of the northern native cat (Dasyurus hallucatus): behavioural and anatomical estimates. Behav Brain Res 22:211-216.

Hart NS (2001): Variations in cone photoreceptor abundance and the visual ecology of birds. J Comp Physiol A 187:685-697.

-Hart NS (2002): Vision in the peafowl (Aves: Pavo cristatus). J Exp Biol 205:3925-3953.

- Hart NS, Partridge JC, Cuthill IC (1998): Visual pigments, oil droplets and cone photoreceptor distribution in the European starling (Sturnus vulgaris). J Exp Biol 201:1433-1446.

Hayes BP (1982): The structural organization of the pigeon retina. J Prog Retinal Res 1:193221.

Hayes BP, Holden AL (1983): The distribution of displaced ganglion cells in the retina of the pigeon. Exp Brain Res 49:181-188.
Hill GE (1993): House finch (Carpodacus mexicanus); in Poole A (ed): The Birds of North America Online. Ithaca, Cornell Lab of Ornithology. http://bna.birds.cornell.edu/bna/ species/046.

Hodos W, Erichsen JT (1990): Lower-field myopia in birds: an adaptation that keeps the ground in focus. Vision Res 30:653-657.

Hughes A (1977): The topography of vision in mammals of contrasting life style: comparative optics and retinal organization; in Crescitelli F (ed): The Visual Systems of Vertebrates. Handbook of Sensory Physiology. New York, Springer, vol VII/5, pp 613-756.

Ikushima M, Watanabe M, Ito H (1986): Distribution and morphology of retinal ganglion cells in the Japanese quail. Brain Res 376: 320-334.

-Inzunza O, Bravo H, Smith RL, Angel M (1991): Topography and morphology of retinal ganglion cells in Falconiforms: a study on predatory and carrion eating birds. Anat Rec 223: 342-346.

- Katzir G, Schechtman E, Carmi N, Weihs D (2001): Head stabilization in herons. J Comp Physiol A 187:423-432.

Kiltie RA (2000): Scaling of visual acuity with body size in mammals and birds. Funct Ecol 14:226-234.

Kirk EC, Kay RF (2004): The evolution of high visual acuity in the Anthropoidea; in Ross CF, Kay RF (eds): Anthropoid Origins: New Visions. New York, Kluwer/Plenum, pp 539602 .

Lima SL, Bednekoff PA (1999): Back to the basics of antipredatory vigilance: can nonvigilant animals detect attack? Anim Behav 58:537543.

Lowther PE (1993): Brown-headed cowbird (Molothrus ater); in Poole A (ed): The Birds of North America Online. Ithaca, Cornell Lab of Ornithology. http://bna.birds.cornell. edu/bna/species/047.

Lowther PE, Calvin LC (2006): House Sparrow (Passer domesticus); in Poole A (ed): The Birds of North America Online. Ithaca, Cornell Lab of Ornithology. http://bna.birds. cornell.edu/bna/species/012.

Martin GR (1985): Eye; in King AS, McLelland J (eds): Form and Function in Birds. London, Academic Press, vol III, pp 311-371.

Dolan/Fernández-Juricic 
Martin GR (1986): The eye of a passeriform bird, the European starling (Sturnus vulgaris): eye movement amplitude, visual fields and schematic optics. J Comp Physiol A 159:545-557.

Martin GR (1993): Producing the image; in Zeigler HP, Bischof HJ (eds): Vision, Brain and Behaviour in Birds. Cambridge, MIT Press, pp 5-24.

- McNamara JM, Houston AI, Lima SL (1994): Foraging routines of small birds in winter - a theoretical investigation. J Avian Biol 25: 287-302.

Meyer DBC (1977): The avian eye and its adaptations; in Crescitelli F (ed): The Visual Systems of Vertebrates. Handbook of Sensory Physiology. New York, Springer, vol VII/5, pp 549-612.

Miles FA, Wallman J (eds) (1993): Visual Motion and Its Role in the Stabilization of Gaze. Amsterdam, Elsevier.

Moroney MK, Pettigrew JD (1987): Some observations on the visual optics of kingfishers (Aves, Coraciformes, Alcedinidae). J Comp Physiol A 160:137-149.

- Necker R (2007): Head-bobbing of walking birds. J Comp Physiol A 193:1177-1183.

Otis, DL, Schulz JH, Miller D, Mirarchi RE, Baskett TS (2008): Mourning dove (Zenaida macroura); in Poole A (ed): The Birds of North America Online. Ithaca, Cornell Lab of Ornithology. http://bna.birds.cornell. edu/bna/species/117.
Pettigrew JD, Dreher B, Hopkins CS, McCall MJ, Brown M (1988): Peak density of ganglion cells in the retinae of microchiropteran bats: implications for visual acuity. Brain Behav Evol 32:39-56.

Rahman ML, Aoyama M, Sugita S (2006): Number, distribution and size of retinal ganglion cells in the jungle crow (Corvus macrorhynchos). Anat Sci Int 86:252-259.

Rahman ML, Aoyama M, Sugita S (2007): Regional specialization of the tree sparrow Passer montanus retina: ganglion cell density and oil droplet distribution. Ornithol Sci 6:95-105.

Reymond L (1985): Spatial visual acuity of the eagle Aquila audax: a behavioural, optical and anatomical investigation. Vision Res 25: 1477-1491.

Reymond L (1987): Spatial visual acuity of the falcon, Falco berigora: a behavioural, optical and anatomical investigation. Vision Res 27 1859-1874.

Ross, CF (2000): Into the light: the origin of Anthropoidea. Annu Rev Anthropol 29:147-94

Roth TC, Lima SL, Vetter WE (2006): Determinants of predation risk in small wintering birds: the hawk's perspective. Behav Ecol Sociobiol 60:195-204.

Stone J (1981): The Wholemount Handbook. A Guide to the Preparation and Analysis of Retinal Wholemounts. Sydney, Maitland Publishing.
Thomas RJ, Kelly DJ, Goodship NM (2004): Eye design in birds and visual constraints on behavior. Ornitol Neotrop 15:243-250.

Thomas RJ, Szekely T, Powell RF, Cuthill IC (2006): Eye size, foraging methods and the timing of foraging in shorebirds. Funct Ecol 20:157-165.

Tiao YC, Blakemore C (1976): Regional specialization in the golden hamster's retina. J Comp Neurol 168:439-457.

Tisdale V, Fernández-Juricic E (2009): Vigilance and predator detection vary between avian species with different visual acuity and coverage. Behav Ecol DOI:10.1093/beheco/ arp080.

Vaney DI (1980): The grating acuity of the wild European rabbit. Vision Res 20:87-90.

von Campenhausen M, Kirschfeld K (1998): Spectral sensitivity of the accessory optic system of the pigeon. J Comp Physiol A 183: $1-6$.

Walls GL (1942): The Vertebrate Eye and Its Adaptive Radiation. New York, Harper.

Wathey JC, Pettigrew JD (1989): Quantitative analysis of the retinal ganglion cell layer and optic nerve of the barn owl Tyto alba. Brain Behav Evol 33:279-292.

$\checkmark$ Williams DR, Coletta NJ (1987): Cone spacing and the visual resolution limit. J Opt Soc Am A 4:1514-1523. 